\title{
ANNUAL BUSINESS REPORT AS A SOURCE OF INFORMATION TO USERS OF FINANCIAL STATEMENTS
}

\section{Duško Šnjegota* Branka Milošević Šnjegota²}

'University of Banja Luka, Faculty of Economics,

Banja Luka, Bosnia and Herzegovina ${ }^{2}$ High School of Economics,

Banja Luka, Bosnia and Herzegovina

\begin{abstract}
:
The Annual Business Report is an obligatory component in the external reporting process played by business entities, usually those who are considered to have public accountability (quoting companies, public companies, banks, insurance companies, investment funds, etc.). Although in accordance with the relevant international accounting regulations they do not form an integral part of the Annual Financial Report (general purpose), bonds of its preparation are mainly presented exactly by information that, by their very nature, belongs to the financial statement, including notes ti financial statements. This paper is devoted to the analysis of the usual reporting practice through the Annual Business Report in the area of the former Yugoslavia. The aim is to point out possible improvements to the existing legal and reporting practices so that, especially external users of information on the operations of publicly-accountable reporting entities, get the highest quality information they need to make various business decisions.
\end{abstract}

Keywords:

Annual Business Report, Annual Financial Report, external users, public accountability

\section{INTRODUCTION}

Financial reporting in the countries of the former Yugoslavia has long been based on the application of the International standard of financial reporting (IFRS). The most common reporting formats are those in which the users of financial statements get presentation of information about financial position of the reporting entity, adequacy of cash flows and cash equivalents generated in the reporting period, changes in personal equity and the like. Even though the application of international standards, unlike principles of traditional financial reporting, made it possible to focus reporting significantly shifted from the past to the present or even the future, making the information in the financial statements made especially more relevant for users, such as investors the fact is that the usual way of reporting does not provide a sufficient amount and quality of information necessary in making business and other decisions by the various categories of users. Eventually, it turned out that for users of financial statements, other than purely financial, it is necessary to present the various non-financial information that belong to the primary area of business reporting. The system which is in a way the boundaries between the financial and the business, and external and internal reporting, commonly referred to as an integrated reporting system through which customers, through a report presented information on social, environmental and

Correspondence:

Duško Šnjegota

e-mail:

dusko.snjegota@ef.unibl.org economic aspects of business reporting entity. Although, it is not a direct result of listed companies as intend other entities important to introduce a system of integrated reporting, annual business report presents an essential component of that system. Depending on the applied legislation, through this report, among other 
things, present information on the risks to which the reporting entity is exposed, assessing the expected future development, the events that occurred between the date of the financial statements and the date of their adoption and publication, applied the rules of corporate management and others. The aim of this study was to identify the rules of reporting through the annual reports of the former $\mathrm{Yu}$ goslavia, assess the extent to which it essentially as such can contribute to an appropriate level of satisfaction more or less complex information needs of stakeholders information on the operations of the reporting entity, and to provide specific recommendations whose implementation would be supported by the transition from the current activities to the concept of integrated reporting.

\section{LITERATURE REVIEW}

The initial develeopment of the international framework for integrated reporting under the auspices of the International Integrated Reporting Council (IIRC) asted nearly 4 years and ended in late 2013. According to this Framework (International Integrated Reporting Council - IIRC, 2013), an integrated report is a concise communication on how the organization's strategy, governance, performance and prospects in the context of its external environment can lead to the creation of value in the short, medium and long term (Integrated Reporting, 2018) he main purpose of integrated reporting is that providers of financial capital (own and borrowed, op. aut.) Through a variety of financial and nonfinancial information to explain the organization over time creates some (added) value.

International Federation of Accountants (IFAC) also strongly supports the establishment of the concept of integrated reporting. According to the organization, integrated reporting is the way to achieve a more coherent system of corporate reporting, by fulfilling the need for a report through which provides a more complete picture of the organization's ability to create value. Integrated Report can be used as a "roof report" for a wide range of other reports, including financial, providing greater interconnectivity between them and a better understanding of all aspects of the reporting entity by different groups of stakeholders. IFAC also strongly supports the action of IIRC and the application of the International framework for integrated reporting.

The paper entitled Integrated reporting and investors (Seraphim, 2014) presented the results of research that analyzes the relationship between the integrated reporting and the quality of the structure of a base of investors who are interested in investing in certain companies. The author concluded that the investments in companies that have a system of integrated reporting long-term oriented investors have shown a significantly higher interest as compared to provisional, that is, investors are willing to invest from predominantly speculative reasons. In his view, this statement is truer for companies that have ta potential for strong growth and are not considered family-owned companies. The paper Research program on integrated reporting - a new theory and practice in the emerging (Dragu and Tiron, 2014), a work in which the authors present the essence of the basic theory relating to the implementation of a new concept of reporting the results of the review of the previous literature in the field of publishing information on the operations and sustainability of corporations, non-financial reporting, etc., in order to understand the diffusion of information and preparation of integrated reports. In addition to these, and many other foreign authors in recent years have devoted special attention to the importance of this concept of reporting on what data can be found on the relevant web pages. In Malinić and Savić' view (2011), the overall responsibility of enterprises by stakeholders can be classified as a financial and strategic dimension. Survival of the business on going concern basis assumes that the company fulfills the two types of liability, or to create a satisfactory level of value for all stakeholders which is why, according to the author, the general public should be informed about all aspects of business. The paper Accounting non-financial reporting - in response to the challenges of modern enterprise management (Malinić, 2015) by, among other things, represents the characteristics of the dominant concepts of financial reporting, with a particular focus placed on the concept of the accounting non-financial reporting, its substance and the necessary present, time, space, the user and organizational and functional basis. It is considered as one of the most important areas of non-financial reporting, the relationship of this concept as a segment accounting information system and modern enterprise management. In the authors' paper Integrated Reporting - a new approach to corporate reporting and governance (Prošić, 2015), integrated reporting is an opportunity to present a comprehensive picture of the business in a clear, concise, coherent and comparable way. The idea of an integrated reporting and integration with non-financial data in the annual report brings many advantages and benefits compared to the existing model of corporate reporting. This approach to the reporting entity and the community as a whole makes it possible to consider the substantive issues facing the business and shows how to create value for shareholders and society as a whole. Integrated reporting in recent years becomes a theme-represented in other relatively numerous scientific papers prepared by local authors. 
Our research question ios: "Did the preparation and presentation of the annual business reports by companies on the territory of the former Yugoslavia contribute to the development of the concept of an integrated report to the higher awareness of stakeholders on the economic as well as social and environmental aspects of the business entity reporting"? For the purpose of research, publicly available data on the business of companies in Bosnia and Herzegovina, Serbia, Montenegro, Croatia and Macedonia were used. Those are mostly companies whose securities are quoted on the stock exchange. The aim of this study was to analyze the existing practice in this regard and indicate the possible improvement in the structure and quality of the annual report on operations which, in accordance with the relevant legal regulations, present in the countries of the former Yugoslavia, and answer the question whether the perspective was justified and realistic as possible to carry out the integration of the report of the comprehensive report produced in the integrated reporting system. In this regard, we formulated the main working hypothesis that reads "Further development of the standard system of corporate financial reporting can ensure better information for stakeholders on all aspects of the reporting entity". Auxiliary hypothesis is defined in order to prove that the Annual Business Report can be an integral part of a comprehensive report on operations generated in the integrated reporting system.

Methodology The research undertaken for the purpose of proving hypotheses includes methods of analyzing the relevant legislation in this area and existing reporting practices in order to present non-financial information and indicators, with a particular focus on reporting through annual performance reports, comparisons statutory provisions with practices prevalent in the country in the former Yugoslavia, the logical conclusion of the results of our research, inductive-deductive conclusion in order to assess the extent to which information is presented through the annual reports on the operations correspond to information which is expected to generate an integrated reporting system, and whether and to what extent the development of an integrated system of reporting on local areas could contribute to the process of decision making, descriptions of the purpose of describing the results obtained, and others. The research was carried out on selected non-statistical sample of companies whose financial and other reports are available publicly on stock exchanges in the former Yugoslavia or on their own websites. The authors believe that this method of selection of a company under observation does not diminish the relevance of results because it is a relatively significant number of listed and other companies in this particular case make the key constructive legal obligation to present annual reports on the operations and one of which is really possible to expect the application of the integrated reporting concept.

\section{RESULTS OF RESEARCH AND DISCUSSION}

According to the results of the research, issues relating to the obligation to prepare annual or other similar statements of operations are mostly regulated through three types of material regulations, in almost all cases directly through a law that applies to the area of accounting (and audit) and the standards of corporate management, and indirectly, by determining the obligations and responsibilities of management or supervisory bodies, the regulations governing issues of importance for the establishment and operation of business / trade companies, public enterprises and the like. All surveyed countries, naturally, have adopted regulations governing the various issues in the field of accounting, provided that the laws in force in Slovenia and Macedonia cannot find the provisions relating to the obligation to prepare annual reports on the operations. Similarly, all countries have adopted standards of corporate governance, noting that there are no significant differences in their content, which is a result of the fact that it is generally accepted standards developed by the Organization for Economic Cooperation and Development (OECD), incorporated into local business practices.

According to the provisions of the law regulating the sphere of accounting (and audit), the annual business report should necessarily include all significant events occurred in the period since the end of the financial year to the date of the financial statements, assessing the expected future development of society, the most important activities related to research and development, information on the repurchase of own shares and share information on business segments, used financial instruments, provided this is important for the assessment of the financial position and performance of the company's operations, objectives and policy of the company regarding the management of financial risks, along with policies to protect against the risk of each planned transaction for which protection is required and information on the exposure to price, credit, market and currency risk, liquidity risk and other risks inherent in the business. Annual Report on the operations of companies whose securities are listed on an organized securities market must contain and display the applied corporate governance rules. Defined in this manner, the annual business report objectively contains a significant portion of non-financial information. Alongside with the information from the annual financial statements those non-financial information could represent important parts of the report that would be generated in the system of integrated reporting. 
More important content (non-financial) report was certainly the one whose preparation is expected of companies, primarily among those listed above, which are obliged to apply the standards of corporate governance. According to the standard of corporate governance 13 - Disclosure and transparency of information, the company should provide timely publication and release of material information related to it, including the financial situation, business ownership and are managed by the company. Public disclosure of financial reports and other information society should enable the assessment of its value from the standpoint of legal status, financial position, business opportunities and rights in connection with securities, a report must contain comprehensible comments and analysis of business by the company management. All interested parties to make available relevant information on the operation and activities of the company, as well as all information about facts and circumstances that could have a significant impact on the share price of the company and to ensure the disclosure of information on development plans and their impact on the economic and social position of employees, trends and changes in salaries, protection and safety at work and measures to improve working conditions, the company's objectives, majority of owners, members of management and supervisory board members and their incomes, the reasons for the eventual resignation or termination of the contract and information about the auditor, the manner of distribution of profits, statutory changes, changes in company form and the establishment of the company, the policy of managing the company, transactions with related parties, foreseeable material risk factors and mechanisms for managing those risks (not in the field of trade secrets), issues related to employees and other stakeholders to work society, structure and management policy and the rights granted to the management to buy company's shares at lower prices than the market price (as the variable component payment for their work), published the takeover bid, changes in the portfolio of shares of individual members administrative/supervisory board and the like.

According to the results of the research, the official websites of all regulated markets of capital (stock exchange) which are organized in each of the surveyed countries in the former Yugoslavia, as a rule, are regularly published periodical and annual financial and audit reports of issuers of securities, information about significant events, statement on application of corporate governance standards and the like. In the annual reports on the business cannot be found on the websites of all the observed stock exchanges, but a significant number of listed and other, mainly large companies to publish on their own Web pages. A significant fact is that well positioned and the other companies are not publicly disclosed Notes to the annual financial report as part of a prescribed set of annual financial statements, but is incorporated into the audit report. However, it s not sufficiently clear whether it is the notes prepared independently by the management of the reporting entity or with some support by the engaged external auditors. Notes represent the additional source of financial and non-financial information whose purpose is to facilitate the understanding of the financial information included in other components of the financial statements (balance sheet, income statement, etc.). The advantage lies in the fact that it is prepared in relatively pure form, which may include an objective and (financial and non-financial) information that they have their place in the report, which is produced in the integrated reporting system.

Analysis leads to an conclusion that it is a fairly uniform formats and ways of reporting on different aspects of the business that are natural information cannot be presented through the financial statements. This results from the fact that the structure of the annual report on the degree of detail prescribed by the authorized regulatory bodies. However, previous years saw many examples in which $t$ annual reports on the operations substantially equated with the annual financial statements (including the Notes to the financial statements), as well as by publishing practically duplicate procedure of financial reporting, and interested users are deprived of the other primarily non-financial information about the business and other relevant aspects (social, environmental, etc.).

Studies have shown that a standard structure of the correctly prepared (posted) yearly financial report includes basic information on the reporting entity, property and bodies, information on the basic indicators of the operations (including the performance indicators), realized on the base that is identified market segments, the extent, structure and the method of acquiring their own and others' effects, the activities on research and development, investments made in the reporting period, the method of quality management and business risks, environmental protection, business plans activities for the next period and the like. Comparing this with the expected structure, it is concluded that it is mainly adapted to the requirements of legislation in the field of accounting (and audit) and, to a lesser extent, the requirements contained in the standards of corporate governance. In other words, the degree of fulfillment of legislation directly stipulated requirements in terms of transparency of operations is higher in relation to the requirements included in the standards (the so-called "Soft law standards"), and in particular in relation to the requirements that could be considered part of customary norms and rules of business (commercial usages). 


\section{LITERATURE}

The obligation of preparation and presentation of the annual report on operations in the former Yugoslavia is still generally regarded as a mandatory part of the process of annual external financial reporting by businesses, especially those that have been found to have a public responsibility. This is the main reason that a number of reporting entities in the past did not make a particularly significant difference between the annual financial statements and annual report on operations. Information of stakeholders on various aspects of the business (economic, social and environmental) with annual reports on the operations carried out mainly in the extent required by the direct legal provisions. This concept of reporting is still not considered to be a concept of integrated reporting neither it is laid down in the relevant international framework. However, it could be a good start in the process and also a necessary transition to integrated reporting in the future. Bearing in mind that from domestic entities reporting can hardly expect to publicly present the reports whose preparation and publication of the law are not required, one of the main ways of improving the existing reporting practices implies necessary changes to the current legislation in order to create a clear legal prerequisites for, to the extent that the justified, be sure to establish an integrated reporting system.
Malinić, S. (2015). Accounting for non-financial reporting - response to the challenges of the modern enterprise management. Proceedings of the 46th Symposium of the Association of Accountants and Auditors of Serbia, Zlatibor, p. 140 - 160,

Prošić, D. (2015). Integrated Reporting - a new approach to corporate reporting and governance. Master World Ltd., Banking No. 4, p. 62 - 87,

Serafeim G. (2015.) Integrated Reporting and Investor Clientele. https://www.tilburguniversity. edu/upload/9c1f79c69200-40f4-957f-2f7704ad9eea_Serafeim\%20(2014)\%20 -\%20Integrated\%20reporting\%20and\%20investor\%20 clientele.pdf.

I. Dragu, A. Tiron-Tudor (2014). Research agenda on integrated reporting: new emergent theory and practice. Procedia Economics and Finance 15, pp 221 - 227,

Malinić, S., Savić, B. (2011). Transformation of corporate reporting - from financial to business reporting. Economic Horizons, 13 (1), p. 105-124,

http://integratedreporting.org/wp-content/uploads/2015/ 03/13-12-08-THE-INTERNATIONAL-IR-FRAMEWORK -2-1.pdf, inspection carried out on 1th of September 2018

http://integratedreportingsa.org/ircsa/wp-content/uploads/2018/07/Summary_of_Papers_on_Integrate d_

www.ifac.org,

www.oecd.org,

www.bl.berza.com,

www.belex.rs,

www.monenegroberza.com,

www.mse.mk,

www.zse.hr. 